\title{
Metabolism of Both Stereoisomers of Phenylglycine by Different Routes in Flavobacterium F24
}

\author{
By W. J. J. VAN DEN TWEEL* AND J. A. M. DE BONT \\ Department of Microbiology, Agricultural University, Hesselink van Suchtelenweg 4, \\ 6703 CT Wageningen, The Netherlands
}

(Received 7 May 1986; revised 29 August 1986)

\begin{abstract}
Flavobacterium F24 metabolized both stereoisomers of phenylglycine and enzyme studies revealed that L-phenylglycine was transaminated by a constitutive enzyme while the Dstereoisomer was oxidized by a phenazine-methosulphate-dependent $\mathrm{D}$-amino-acid dehydrogenase. This latter enzyme was not induced during growth on L-phenylglycine. Phenylglyoxylate formed in the reactions was decarboxylated by an inducible enzyme to benzaldehyde, which was oxidized mainly by an inducible phenazine-methosulphate-dependent benzaldehyde dehydrogenase not described earlier. Benzoate was further metabolized via 3-hydroxybenzoate to gentisate, which in turn was further degraded through a glutathione-dependent pathway.
\end{abstract}

\section{INTRODUCTION}

The D-enantiomer of 4-hydroxyphenylglycine is an industrially important intermediate in the manufacture of semisynthetic penicillins and cephalosporins. The compound may be synthesized by both chemical and biological procedures. Chemical procedures include the classical resolution of racemic DL-4-hydroxyphenylglycine with $d$-3-bromocamphor-8-sulphonic acid (Yamada et al., 1979) whereas biological methods involve the enantioselective hydrolysis of a derivative such as the amide (Boesten \& Meyer-Hoffman, 1975), the $N$-acetyl acid ester (Schutt, 1981; Schutt et al., 1985), the hydantoin (Cecere et al., 1975, 1978; Takahashi et al., 1979; Nakamori et al., 1980; Olivieri et al., 1979, 1981) or the aminonitrile (Arnaud et al., 1980). Nevertheless, it would be very interesting to have an alternative biological method at hand that would allow a direct regio- and stereospecific hydroxylation of phenylglycine yielding $D(-)-4-$ hydroxyphenylglycine. In order to detect such a possible hydroxylation reaction in bacteria we have isolated various organisms on phenylglycine and recently we have described the metabolism of DL-phenylglycine in Pseudomonas putida (van den Tweel et al., 1986a). The organism however, transaminated both stereoisomers of phenylglycine to phenylglyoxylate and did not hydroxylate phenylglycine.

In this paper we describe the metabolism of both stereoisomers of phenylglycine by a Flavobacterium sp. In this strain also no hydroxylation of phenylglycine was observed, but the metabolism of D-phenylglycine was distinct from that in P.putida (van den Tweel et al., 1986a).

\section{METHODS}

Chemicals. Both stereoisomers of phenylglycine, aminooxyacetate (AOA), $N$-ethylmaleimide and phenazine methosulphate (PMS) were products of Aldrich. DL-2-, DL-3- and DL-4-hydroxyphenylglycine were a gift of OcéAndeno BV, Venlo, The Netherlands. All biochemicals were from Boehringer. All other chemicals were of commercially available analytical grade and were used without further purification.

Isolation and cultivation of strain F24. A mixture of soil and sewage samples was diluted and streaked directly onto agar plates containing a mineral salts medium (van den Tweel et al., 1986a) to which D-phenylglycine $\left(1 \mathrm{~g} \mathrm{l}^{-1}\right)$ was added. Colonies that had appeared after two weeks of incubation were transferred to agar plates containing

Abbreviations: AOA, aminooxyacetate; PLP, pyridoxal phosphate; PMS, phenazine methosulphate. 
the same medium. Strain F24 was isolated by selection of a single colony from these plates. Maintenance and cultivation of strain F24 was as described previously for $P$. putida LW-4 (van den Tweel et al., 1986a).

Simultaneous adaptation experiments. Experiments with washed cells were performed as described previously (van den Tweel et al., 1986a).

Phenylglycine consumption by washed cell suspensions of Flavobacterium F24. The complete reaction mixture (total vol. $5 \mathrm{ml}$ ) contained cells, $250 \mu \mathrm{mol}$ potassium phosphate buffer $\mathrm{pH} 7.0$ and 5 or $10 \mu \mathrm{mol}$ phenylglycine. The reaction tubes were incubated in a shaking water bath $\left(30^{\circ} \mathrm{C}, 1 \mathrm{~Hz}\right)$. Experiments were performed with or without AOA (15 mM). Samples $(0.5 \mathrm{ml})$, taken at intervals, were analysed at room temperature by reversed phase HPLC using a C-18 column ( $200 \times 3 \mathrm{~mm}$; Chrompack, Middelburg, The Netherlands) and detected at $216 \mathrm{~nm}$ by means of a Perkin-Elmer variable wavelength detector. As an eluent a mixture of $50 \mathrm{~mm}$-potassium phosphate buffer pH 7.0 and methanol $(90: 10)$ was used; the flow rate was $0.4 \mathrm{ml} \mathrm{min}^{-1}$. Metabolites were identified by comparison of retention times with authentic samples and by in situ scanning of the UV spectra after the flow had been stopped.

Protein determination. Protein contents of crude cell extracts and whole cells were determined by the Lowry method using crystalline bovine serum albumin as a standard.

Separation of the optical isomers of phenylglycine. Samples were separated by HPLC using a chiral stationary phase column (ET 250/8/4 Nucleosil Chiral-1; Macherey-Nagel, Düren, FRG) and detected at $216 \mathrm{~nm}$ by means of a Perkin-Elmer variable wavelength detector. The mobile phase was aqueous $1.0 \mathrm{~mm}$-copper acetate $\mathrm{pH} 5 \cdot 6$, the flow rate was $0.8 \mathrm{ml} \mathrm{min}^{-1}$, and the column temperature was $60^{\circ} \mathrm{C}$. Under these conditions D- and L-phenylglycine had retention times of 9.25 and $8.55 \mathrm{~min}$ respectively.

Enzyme assays. All assays were done at $30^{\circ} \mathrm{C}$. Cell extracts were prepared as previously described (van den Tweel et al., 1986a).

(i) Phenylglycine transaminase. This enzyme was assayed by measuring the rate of disappearance of phenylglycine by HPLC. The reaction mixture (total vol. $5 \mathrm{ml}$ ) contained cell extract, $25 \mu \mathrm{mol} 2$-oxoglutarate, $1 \mu \mathrm{mol}$ PLP and $250 \mu \mathrm{mol}$ potassium phosphate buffer $\mathrm{pH} 7 \cdot 0$. The reaction was started by the addition of $5 \mu \mathrm{mol}$ phenylglycine. Samples $(0.5 \mathrm{ml})$, taken at intervals, were analysed by HPLC using the same conditions as described for the analysis of the mixture during the incubation of washed cells with phenylglycine.

(ii) Phenylglycine dehydrogenase (PMS-dependent). This enzyme was assayed by recording the oxygen uptake with a polarographic oxygen monitor. The reaction mixture (total vol. $3 \mathrm{ml}$ ) contained $150 \mu \mathrm{mol} \mathrm{Tris} / \mathrm{HCl}$ buffer pH $9.0,0.33 \mu \mathrm{mol}$ PMS and cell extract. The reaction was initiated by the addition of $3 \mu \mathrm{mol}$ substrate. Alternatively, the enzyme activity was recorded by measuring phenylglycine concentrations at various intervals. The complete reaction mixture (total vol. $5 \mathrm{ml}$ ) contained cell extract, $250 \mu \mathrm{mol}$ Tris/ $\mathrm{HCl}$ buffer pH 9.0 and $5 \mu \mathrm{mol}$ PMS. The reaction was started by adding $10 \mu \mathrm{mol}$ phenylglycine. Samples were analysed for phenylglycine by HPLC (conditions as before).

(iii) Phenylglycine hydroxylase. The possible presence of phenylglycine hydroxylase activity was investigated using the procedure described by Guroff \& Ito (1964) for phenylalanine hydroxylase, except that phenylalanine was replaced by phenylglycine.

(iv) Phenylglycine dehydrogenase $\left[N A D(P)^{+}\right.$-dependent $]$. The presence of an $\mathrm{NAD}(\mathrm{P})^{+}$-dependent enzyme was assayed for in a way similar to phenylalanine dehydrogenase (Hummel et al., 1984), except that phenylalanine was replaced by phenylglycine.

(v) Phenylglycine oxidase. The presence of a possible phenylglycine oxidase was investigated by means of a polarographic oxygen probe. The reaction mixture (total vol. $3 \mathrm{ml}$ ) contained $150 \mu \mathrm{mol}$ buffer (either potassium phosphate $\mathrm{pH} 7.0$ or $\mathrm{Tris} / \mathrm{HCl} \mathrm{pH} \mathrm{9.0)}$ and cell extract. The reaction was started by the addition of $3 \mu \mathrm{mol}$ phenylglycine.

(vi) Phenylglyoxylate decarboxylase (Benzoylformate carboxy-lyase, EC 4.1.1.7). Phenylglyoxylate consumption by cell extracts was measured as described previously (van den Tweel et al., 1986a). Samples were analysed by HPLC using the same conditions as described above.

(vii) Benzaldehyde dehydrogenase ( $P M S-$ dependent). This enzyme was also assayed by means of a polarographic oxygen probe. The reaction mixture (total vol. $3 \mathrm{ml}$ ) contained $150 \mu \mathrm{mol}$ Tris/HCl buffer $\mathrm{pH} 9 \cdot 0,0.33 \mu \mathrm{mol}$ PMS and cell extract. The reaction was initiated by the addition of $3 \mu \mathrm{mol}$ benzaldehyde.

(viii) Benzaldehyde dehydrogenase $\left[N A D(P)^{+}\right.$-dependent]. Activity of this enzyme was measured as described previously (van den Tweel et al., 1986a).

(ix) Gentisate 1,2-dioxygenase (EC 1.13.11.4). Activity of this enzyme was measured spectrophotometrically as described by Crawford et al. (1975).

\section{RESULTS}

\section{Taxonomic studies and growth characteristics of strain F24}

Strain F24, isolated from soil, was a bright yellow, strictly aerobic, Gram-negative, motile rod, which was not able to grow at $37^{\circ} \mathrm{C}$. It did not produce acid from glucose, was unable to 
Table 1. Rates of oxygen uptake by washed cell suspensions of Flavobacterium F24 cultivated on various carbon sources

\begin{tabular}{|c|c|c|c|}
\hline \multirow[b]{2}{*}{ Substrate } & \multicolumn{3}{|c|}{$\begin{array}{c}\text { Rate of oxygen uptake* } \\
{\left[\mathrm{nmol} \mathrm{O}_{2} \mathrm{~min}^{-1}(\mathrm{mg} \text { protein })^{-1}\right]} \\
\text { by cells grown on }\end{array}$} \\
\hline & D-Phenylglycine & L-Phenylglycine & Succinate \\
\hline D-Phenylglycine & 70 & 5 & 0 \\
\hline L-Phenylglycine & 35 & 40 & 0 \\
\hline DL-2-Hydroxyphenylglycine & 5 & 5 & 0 \\
\hline DL-3-Hydroxyphenylglycine & 5 & 5 & 0 \\
\hline DL-4-Hydroxyphenylglycine & 5 & 5 & 0 \\
\hline Phenylglyoxylate & 65 & 60 & 0 \\
\hline Benzaldehyde & 50 & 55 & 0 \\
\hline Benzoate & 50 & 40 & 0 \\
\hline 2-Hydroxybenzoate & 0 & ND & 0 \\
\hline 3-Hydroxybenzoate & 20 & 20 & 0 \\
\hline 4-Hydroxybenzoate & 0 & 0 & 0 \\
\hline Catechol & 0 & 0 & 0 \\
\hline Gentisate & 20 & 15 & 0 \\
\hline Protocatechuate & 0 & 0 & 0 \\
\hline 2,3-Dihydroxybenzoate & 0 & ND & 0 \\
\hline Succinate & 20 & 30 & 50 \\
\hline
\end{tabular}

ND, Not determined.

* Rates are the means of results from at least two separate cell suspensions and are corrected for endogenous oxygen uptake.

form spores, or to denitrify and was both oxidase- and aminopeptidase-positive. Gelatine and aesculin were not hydrolysed and $\beta$-galactosidase, urease and arginine dihydrolase were not produced. Strain F24 was able to use the following compounds as sole carbon and energy source: D- and L-phenylglycine, phenylglyoxylate, DL-mandelate, D- and L-phenylalanine, D- and Ltyrosine, 3- and 4-hydroxybenzoate, phenylacetate, acetate, pyruvate, succinate, 3-hydroxybutyrate and glucose. On D- and L-phenylglycine doubling times of 10 and $12 \mathrm{~h}$ respectively were observed. Using succinate as carbon source strain F24 doubled in $2.5 \mathrm{~h}$. No growth was observed when using DL-2-, DL-3- or DL-4-hydroxyphenylglycine, benzylalcohol, 2-phenylethanol or malonate as potential growth substrates at $1.0 \mathrm{~g} \mathrm{1}^{-1}$. Surprisingly, strain F24 did not grow on benzoate $\left(0.25,0.5\right.$ or $\left.1.0 \mathrm{~g} \mathrm{l}^{-1}\right)$ and the addition of benzoate $\left(0.05 \mathrm{gl}^{-1}\right)$ to a mineral salts medium containing D-phenylglycine $\left(1.0 \mathrm{~g} \mathrm{l}^{-1}\right)$ inhibited growth.

Strain F24, on the basis of the above taxonomic results and its growth characteristics, was tentatively identified as a member of the genus Flavobacterium.

\section{Incubation experiments with whole cells}

The ability of intact cells to oxidize possible intermediates in the metabolism of phenylglycine was tested indirectly by measuring rates of oxygen uptake by intact cells grown on either D- or Lphenylglycine or on succinate (Table 1). Both D- and L-phenylglycine-grown cells showed good initial rates of oxidation of L-phenylglycine, phenylglyoxylate, benzaldehyde, benzoate, 3hydroxybenzoate and gentisate (2,5-dihydroxybenzoate). D-Phenylglycine-grown cells also readily metabolized D-phenylglycine while L-phenylglycine-grown cells did not. Hydroxylated phenylglycine derivatives, which would be intermediates in the case of an initial hydroxylation, were not oxidized by D- or L-phenylglycine-grown cells. Flavobacterium F24 cells grown on succinate did not oxidize the aromatic compounds tested.

Phenylglycine metabolism by washed cells was also tested directly by measuring the disappearance of substrates from incubation mixtures by HPLC. Cells grown on Dphenylglycine readily metabolized both phenylglycine isomers (Fig. 1). The L-stereoisomer, however, was metabolized at about half the rate of D-phenylglycine metabolism (Fig. 1c). 

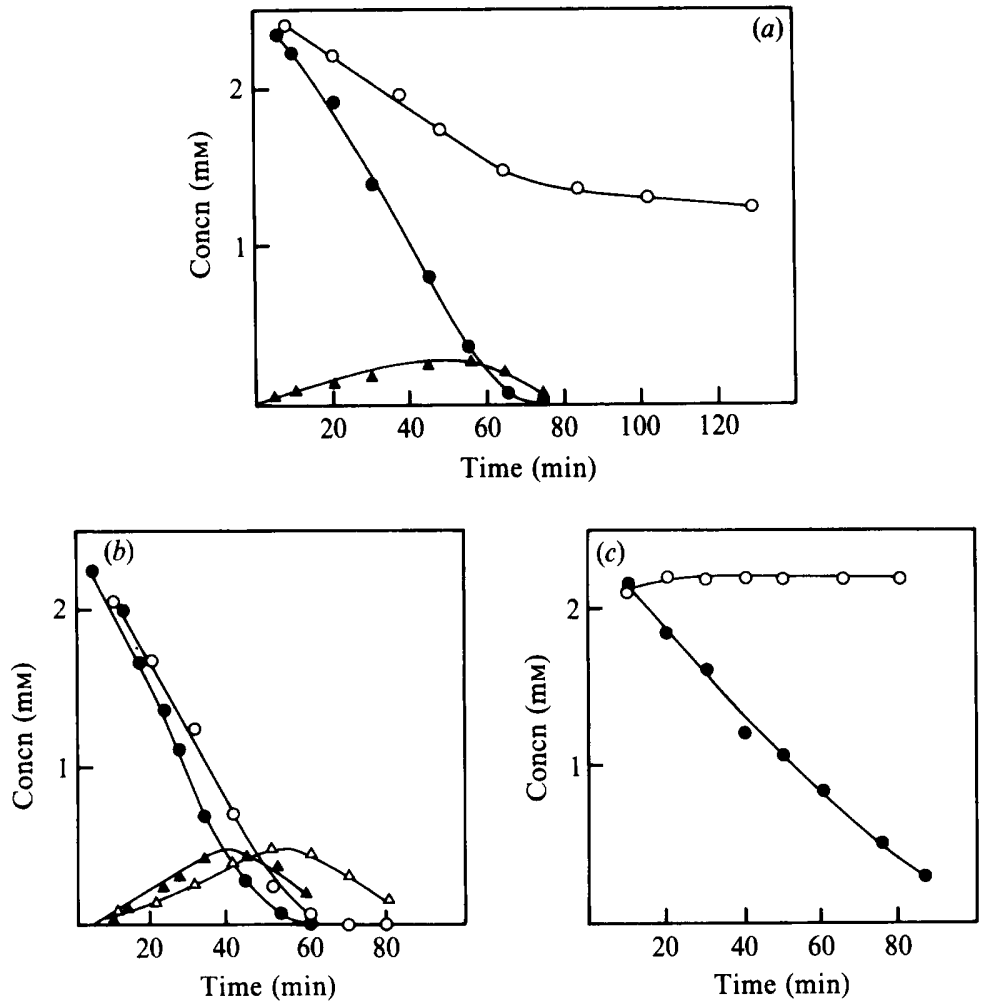

Fig. 1. Phenylglycine consumption $(O, O)$ and benzoate accumulation $(\Delta, \Delta)$ by cell suspensions of Flavobacterium F24 cultivated on D-phenylglycine. The incubation mixture $(5 \mathrm{ml})$ contained $15.5 \mathrm{mg}$ protein and $10 \mu \mathrm{mol}$ phenylglycine: $(a)$ DL-phenylglycine, $(b)$ D-phenylglycine, $(c)$ L-phenylglycine. The incubation was in the presence $(O, \triangle)$ or absence $(O, \triangle)$ of $A O A$.

During the incubations with DL- and D-phenylglycine a product transiently accumulated (Fig. $1 a, b)$ which was identified as benzoate according to its retention time and UV absorption characteristics. No benzoate accumulated during the incubation with L-phenylglycine (Fig. $1 c$ ). Similar experiments were also performed in the presence of $15 \mathrm{mM}$-aminooxyacetate (AOA), a pyridoxal phosphate (PLP) inhibitor (Hotta, 1968), to investigate whether D- and/or Lphenylglycine were initially transaminated as described for Pseudomonas putida LW-4 (van den Tweel et al., 1986a). L-Phenylglycine metabolism was completely prevented in the presence of AOA, indicating that a PLP-dependent enzyme is involved in the metabolism of this stereoisomer (Fig. 1c). However, when this experiment was performed with D-phenylglycine as substrate, no inhibition was observed (Fig. $1 b$ ). Incubation with DL-phenylglycine in the presence of AOA resulted in phenylglycine metabolism until $50 \%$ of the mixture was utilized (Fig. 1a). Different results were obtained with Flavobacterium F24 cells cultivated on Lphenylglycine. Such cells consumed about $50 \%$ of racemic DL-phenylglycine, did not metabolize D-phenylglycine, and readily metabolized L-phenylglycine. In the presence of the PLP inhibitor AOA, no consumption of DL-phenylglycine or of L-phenylglycine could be measured.

Washed suspensions of D-phenylglycine-grown cells were also incubated with either DL-2-, DL3- or DL-4-hydroxyphenylglycine but this did not result in a decrease in concentration of these substrates, indicating that no hydroxylated phenylglycine derivative is involved in Dphenylglycine metabolism in this species.

\section{The initial step in the metabolism of $\mathrm{D}$ - and L-phenylglycine}

From the above results it was suspected that in strain F24 D- and L-phenylglycine are degraded by two different enzymes; this hypothesis was tested in in vitro experiments. Cell extracts of D- 

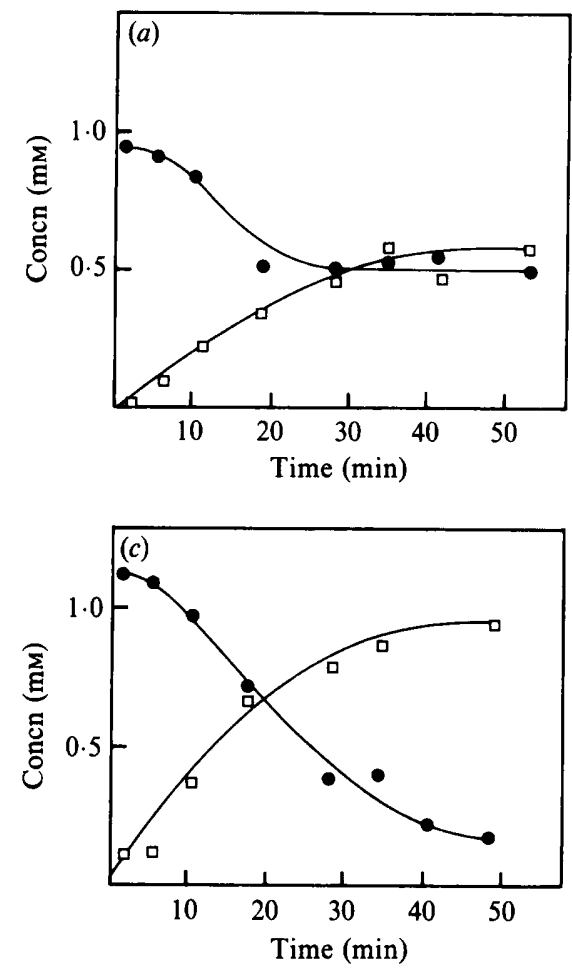

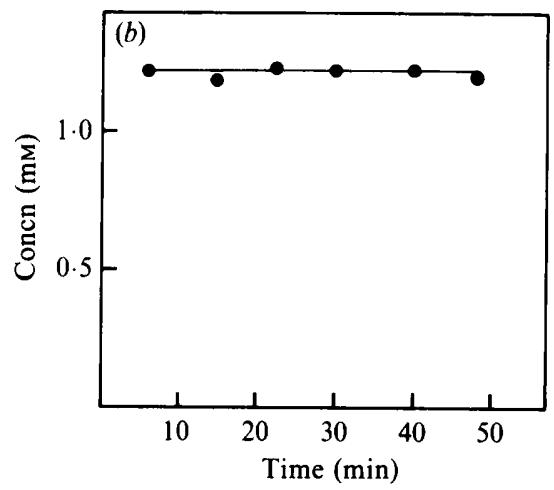

Fig. 2. Transamination of phenylglycine (O) and phenylglyoxylate accumulation $(\square)$ by cell extracts of Flavobacterium F24 cultivated on D-phenylglycine. The reaction mixture contained $15 \mathrm{mg}$ protein. $(a)$ Incubation with DL-phenylglycine; (b) with D-phenylglycine; (c) with L-phenylglycine. Similar results were obtained using extracts of cells grown on L-phenylglycine (data not shown).

Table 2. Specific enzyme activities of some enzymes involved in phenylglycine degradation in Flavobacterium F24 cultivated on various carbon sources

\begin{tabular}{|c|c|c|c|}
\hline \multirow[b]{2}{*}{ Enzyme } & \multicolumn{3}{|c|}{$\begin{array}{l}\text { Specific enzyme activity* } \\
\left.\text { [nmol } \mathrm{min}^{-1}(\mathrm{mg} \text { protein })^{-1}\right] \\
\text { of extracts of cells grown on }\end{array}$} \\
\hline & D-Phenylglycine & L-Phenylglycine & Succinat \\
\hline -phenylglycine dehydrogenase & 45 & 5 & 0 \\
\hline ansaminase & 10 & 10 & 10 \\
\hline $\begin{array}{l}\text { decarboxylase } \\
\text { ydrogenase }\end{array}$ & 10 & 5 & 0 \\
\hline nt & 5 & 5 & 5 \\
\hline & 225 & 200 & 5 \\
\hline ygenase & 15 & 15 & 0 \\
\hline
\end{tabular}

* The activities are the means of results from two separate extracts.

and L-phenylglycine-grown cells consumed approximately $50 \%$ of racemic DL-phenylglycine in the simultaneous presence of PLP and 2-oxoglutarate (Fig. 2a); under these conditions they did not metabolize D-phenylglycine (Fig. $2 b$ ) but fully transformed L-phenylglycine (Fig. $2 c$ ). Chiral HPLC analysis of the residue after completion of the reaction with DL-phenylglycine (Fig. 2a) showed that only D-phenylglycine was present, indicating that only the L-stereoisomer was transaminated. Replacing 2-oxoglutarate by oxaloacetate, pyruvate or phenylpyruvate also did not result in a transamination of D-phenylglycine. During these incubations (Fig. 2) an almost stoichiometric accumulation of phenylglyoxylate from L-phenylglycine was obtained. Cell extracts of succinate-grown cells were also able to transaminate L-phenylglycine (Table 2). These results show that $L$-phenylglycine is initially transaminated by a constitutive enzyme, but do not 

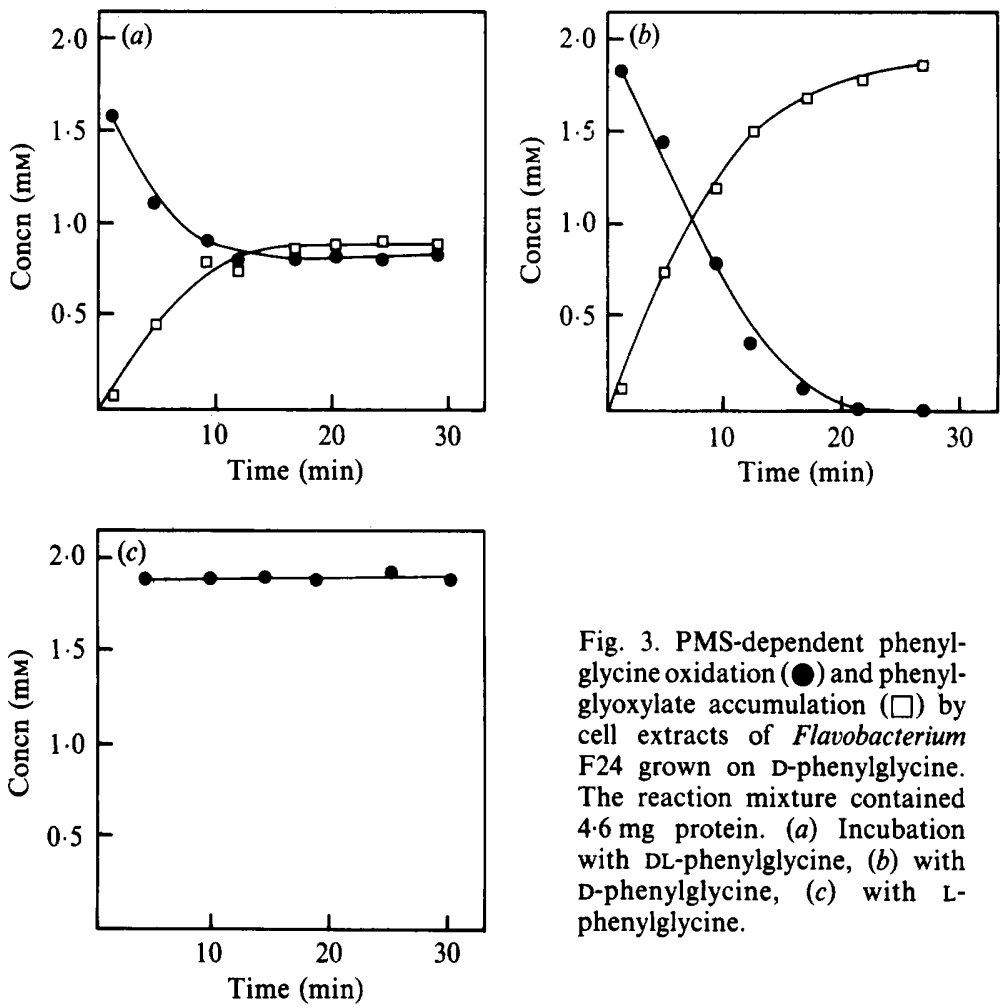

Fig. 3. PMS-dependent phenylglycine oxidation $(O)$ and phenylglyoxylate accumulation ( $\square$ ) by cell extracts of Flavobacterium F24 grown on D-phenylglycine. The reaction mixture contained $4.6 \mathrm{mg}$ protein. (a) Incubation with DL-phenylglycine, (b) with D-phenylglycine, (c) with Lphenylglycine.

reveal the mechanism of $D$-phenylglycine metabolism. Further experiments with cell extracts showed that no D-phenylglycine hydroxylase, no NAP(P)+-dependent dehydrogenase and no oxidase were present in D-phenylglycine-grown cells. However, D-phenylglycine was readily oxidized when PMS was added to cell extracts as measured by oxygen consumption. This rate of oxidation was maximal $\left[165 \mathrm{nmol} \mathrm{m^{-1 }}(\mathrm{mg} \text { protein })^{-1}\right]$ at $\mathrm{pH} 9.5$ using a $50 \mathrm{~mm}$ $\mathrm{Na}_{2} \mathrm{CO}_{3} / \mathrm{NaHCO}_{3}$ buffer. Since PMS is readily auto-oxidized at pH 9.5 and above, further experiments were done at $\mathrm{pH} 9.0$ using a Tris/ $\mathrm{HCl}$ buffer. Fig. 3 shows the results obtained with cell extracts of D-phenylglycine-grown Flavobacterium F24 cells during an incubation at pH 9.0 in the presence of PMS. Under these conditions only $50 \%$ of the DL-phenylglycine was oxidized and at a relatively low rate (Fig. $3 a$ ) when compared with the D-phenylglycine oxidation rate (Fig. $3 b$ ), whereas L-phenylglycine was not oxidized (Fig. 3c). Chiral HPLC analysis of the residue after completion of the reaction with DL-phenylglycine (Fig. $3 a$ ) showed that only Lphenylglycine was left behind. During all these incubations (Fig. 3) D-phenylglycine was converted stoichiometrically to phenylglyoxylate.

Oxygen uptake experiments in the presence of PMS showed that apart from D-phenylglycine several other $\mathrm{D}$-amino acids were oxidized by cell extracts of D-phenylglycine-grown cells whereas L-amino acids were not (Table 3 ). Surprisingly, none of the D-hydroxyphenylglycines could be oxidized while other aromatic D-amino acids were readily oxidized. The apparent Michaelis constant for D-phenylglycine of the enzyme system in cell extracts was $0.65 \mathrm{mM}$.

\section{Phenylglyoxylate decarboxylase}

Both the transamination of L-phenylglycine and the PMS-dependent oxidation of Dphenylglycine resulted in the formation of phenylglyoxylate. This latter compound was very slowly decarboxylated by cell extracts as shown by recording phenylglyoxylate disappearance from incubation mixtures by means of HPLC during incubations with thiamin pyrophosphate (Table 2). When Flavobacterium F24 was grown on succinate no phenylglyoxylate decarboxylase was present (Table 2). 
Table 3. Oxidation of various amino acids by cell extracts of Flavobacterium F24 grown on D-phenylglycine

\begin{tabular}{|c|c|c|c|}
\hline Substrate & $\begin{array}{l}\text { Specific activity } \\
{\left[\mathrm{nmol} \mathrm{O}_{2} \mathrm{~min}^{-1}\right.} \\
\left.(\mathrm{mg} \text { protein })^{-1}\right]\end{array}$ & Substrate & $\begin{array}{l}\text { Specific a } \\
{[\mathrm{nmol} \mathrm{O}} \\
\text { (mg prote }\end{array}$ \\
\hline DL-Phenylglycine & 25 & DL-Isoleucine & 50 \\
\hline D-Phenylglycine & 45 & DL-Valine & 85 \\
\hline L-Phenylglycine & 0 & DL-Leucine & 40 \\
\hline D-Phenylalanine & 55 & DL-Norleucine & 25 \\
\hline D-Tyrosine & 50 & DL-Norvaline & 90 \\
\hline D-Tryptophan & 235 & DL-Ornithine & 15 \\
\hline DL-Histidine & 65 & DL- $\alpha$-Aminobutyrate & 40. \\
\hline DL-5-Hydroxytryptophan & 55 & & \\
\hline
\end{tabular}

No activity was observed with the following substrates: DL-2-, DL-3- or DL-4-hydroxyphenylglycine, L-phenylalanine, L-histidine, L-5-hydroxytryptophan, glycine, DL-alanine, DL-glutamine, DL-asparagine, L-isoleucine, L-valine, L-leucine, DL-aspartate, DL-glutamate, DL-threonine, DL-serine, L-ornithine, L-proline, L-arginine, L-lysine, L-methionine, L-hydroxyproline, L-tyrosine and L-tryptophan.

\section{Oxidation of benzaldehyde}

Flavobacterium $\mathrm{F} 24$ possessed a $\mathrm{NAD}^{+}$-dependent benzaldehyde dehydrogenase which was present both in succinate- and D- or L-phenylglycine-grown cells (Table 2). NADP ${ }^{+}$could not replace $\mathrm{NAD}^{+}$. Along with this constitutive $\mathrm{NAD}^{+}$-dependent aldehyde dehydrogenase an inducible PMS-dependent benzaldehyde dehydrogenase was present in phenylglycine-grown cells. The latter enzyme showed a $\mathrm{pH}$ optimum at $\mathrm{pH}$ 9. The activity of this enzyme was not stimulated by the addition of $\mathrm{NH}_{4} \mathrm{Cl}(15 \mathrm{mM})$. No activity was lost upon dialysis for $24 \mathrm{~h}$.

\section{Further metabolism of benzoate}

Simultaneous adaptation experiments (Table 1) indicated that benzoate was an intermediate in phenylglycine metabolism and that it was metabolized via 3-hydroxybenzoate to gentisate. In spite of this, no enzymic activity for benzoate or 3-hydroxybenzoate oxidation was detected in extracts using either NADH or NADPH as a cofactor. However, experiments with cell extracts confirmed that a gentisate dioxygenase was induced during growth on D- or L-phenylglycine whereas no catechol and protocatechuate dioxygenases were present. The spectral changes observed during cleavage of the benzene nucleus of gentisate at $334 \mathrm{~nm}$ were characteristic of a breakdown via maleylpyruvate (Lack, 1959). Further degradation of maleylpyruvate was dependent upon the addition of reduced glutathione, indicating that a GSH-dependent isomerase is present in this species. Moreover, $N$-ethylmaleimide (NEM), a glutathionetrapping agent (Crawford \& Frick, 1977), completely inhibited the GSH-dependent degradation of maleylpyruvate; this inhibition could be overcome by adding GSH in slight excess over NEM.

\section{DISCUSSION}

The Flavobacterium F24 described here grew on both D- and L-phenylglycine albeit slowly ( $t_{\mathrm{d}} 10$ and $12 \mathrm{~h}$, respectively) when compared with $P$. putida LW-4 (van den Tweel et al., 1986a), which doubled in $1.5-2.0 \mathrm{~h}$ when growing on D-phenylglycine. The low growth rate of Flavobacterium F24 on phenylglycine may explain the rather low specific enzyme activities of some enzymes (Table 2) involved in phenylglycine degradation in this organism. Strain F24 degrades D-phenylglycine by a PMS-dependent D-amino-acid dehydrogenase and this enzyme is induced in the presence of D-phenylglycine. No D-phenylglycine transaminase as present in $P$. putida LW-4 (van den Tweel et al., 1986a) was detected in F24 and unfortunately neither was a phenylglycine hydroxylase detected in this organism. Such mono-oxygenase activity might have been expected to be present in view of the rather broad occurrence of a similar mono-oxygenase employed for the hydroxylation of the analogous compound phenylalanine (Guroff \& Ito, 1964; 


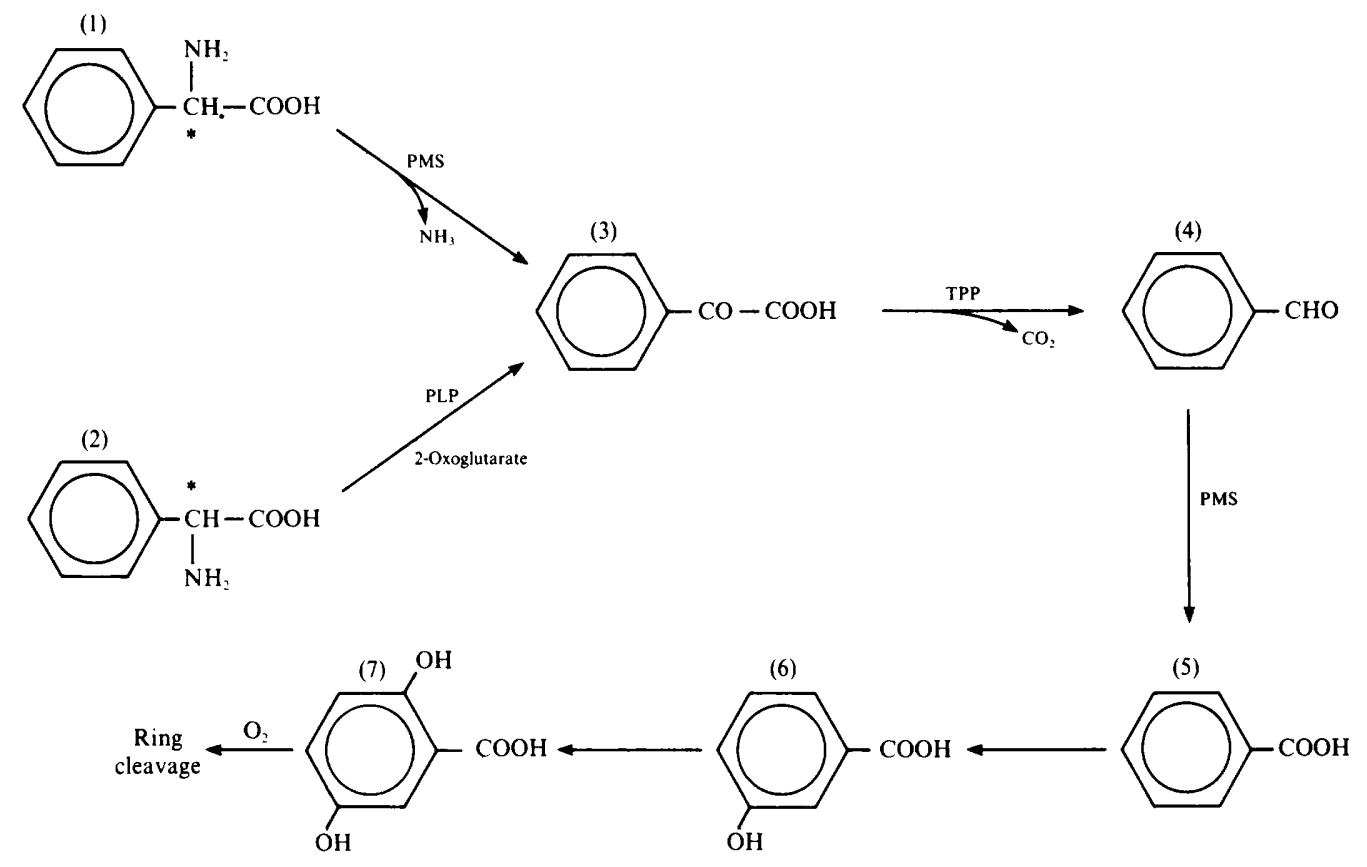

Fig. 4. Proposed pathway for the metabolism of D- and L-phenylglycine in Flavobacterium F24. (1) DPhenylglycine, (2) L-phenylglycine, (3) phenylglyoxylate, (4) benzaldehyde, (5) benzoate, (6) 3hydroxybenzoate, (7) gentisate. TPP, thiamin pyrophosphate.

Chandra \& Vining, 1968; Friedrich \& Schlegel, 1972; Nakata et al., 1979). Since a regio- and stereo-selective phenylglycine mono-oxygenase would be of great interest for a biotechnological formation of $\mathrm{D}(-)$-4-hydroxyphenylglycine we are currently screening several other phenylglycine-utilizing bacteria for such an enzyme. Dye-linked D-amino-acid dehydrogenases are involved in the metabolism of various D-amino acids: D-valine (Marshall \& Sokatch, 1968), allohydroxy-D-proline (Bater et al., 1977), D-tryptophan (Tsukada, 1966) and D-alanine (Pioli et al., 1976) and in general show a fairly broad substrate specificity. The D-amino acid dehydrogenase in D-phenylglycine-grown Flavobacterium F24 cells also oxidized various Damino acids but it should be emphasized that it is not yet known whether this activity is to be ascribed to only one enzyme. L-Phenylglycine on the other hand was metabolized by a constitutive transaminase which showed no activity with the D-stereoisomer of phenylglycine.

Phenylglyoxylate was identified as the product of both the PMS-dependent D-phenylglycine oxidation and the L-phenylglycine transamination. In extracts, it was slowly decarboxylated in the presence of thiamin pyrophosphate. The activity of the phenylglyoxylate decarboxylase was very low when compared with this enzyme activity in $P$. putida LW-4 grown on either D- or Lphenylglycine (van den Tweel et al., 1986a). No NAD(P)+-dependent benzaldehyde dehydrogenase was induced in Flavobacterium F24 cells during growth on D- or L-phenylglycine. Instead a PMS-dependent enzyme showing maximal activity around $\mathrm{pH} 9 \cdot 0$ was detected. Until now, no PMS-dependent aldehyde dehydrogenase has been implicated in the catabolism of aromatic compounds, but several dye-linked aldehyde dehydrogenases are involved in aliphatic aldehyde oxidation (Stirling \& Dalton, 1978). One group of these enzymes, the quinoprotein alcohol dehydrogenases (Duine \& Frank, 1981), may show a requirement for $\mathrm{NH}_{4}^{+}$(Yamanaka, 1981) but the PMS-dependent benzaldehyde dehydrogenase of Flavobacterium F24 did not require $\mathrm{NH}_{4}^{+}$for activity.

Although benzoate presumably is an intermediate in phenylglycine metabolism in Flavobacterium F24, it could not support growth. In fact, benzoate inhibited growth above a 
concentration of $0.05 \mathrm{~g} \mathrm{l}^{-1}$. Inhibition of substrate transport into the cells by benzoate (Freese $e t$ al., 1973) may possibly explain this phenomenon.

From simultaneous adaptation experiments a further oxidation of benzoate via 3hydroxybenzoate to gentisate seems most likely. The fact that neither a benzoate nor a 3hydroxybenzoate hydroxylase could be measured in cell extracts may result from a low stability of these enzymes in vitro. The benzene nucleus of gentisate was cleaved by an inducible dioxygenase yielding maleylpyruvate, which was further degraded by a GSH-dependent reaction sequence. This is in agreement with the fact that until now all Gram-negative organisms have been shown to possess a GSH-dependent gentisate or homogentisate pathway (Hagedorn \& Chapman, 1985; Hagedorn et al., 1985; van den Tweel et al., 1986b).

The results presented in this paper show that Flavobacterium F24 metabolizes both stereoisomers of phenylglycine by the converging pathway shown in Fig. 4.

We are grateful to Professor C. J. E. A. Bulder, Professor K. van 't Riet, Dr J. Tramper and Dr A. Bruggink (Océ-Andeno BV) for advice in preparing the manuscript. These investigations were supported in part by the Netherlands Technology Foundation (STW).

\section{REFERENCES}

Arnaud, A., Galzy, P. \& Jallageas, J.-C. (1980). Production d'acides $\alpha$-aminés stéréospécifiques par hydrolyse biologique d' $\alpha$-aminonitriles racémiques. Société chimique de France 1-2, 87-90.

Bater, A. J., Venables, W. A. \& Thomas, S. (1977). Allohydroxy-D-proline dehydrogenase. An inducible membrane-bound enzyme in Pseudomonas aeruginosa PAO1. Archives of Microbiology 112, 287-289.

Boesten, W. H. \& Meyer-Hoffman, L. R. M. (1975). Enzympreparaat met aminopeptidase activiteit. Dutch Patent Application no. 7513551.

Cecere, F., Galli, G. \& Morisi, F. (1975). Substrate and steric specificity of hydropyrimidine hydrase. FEBS Letters 57, 192-194.

Cecere, F., Galli, G., Della Penna, G. \& Rappuoli, B. (1978). Process for producing D-carbamoyl amino acids and the corresponding D-amino acids. British Patent no. 1506067.

Chandra, P. \& Vining, L. C. (1968). Conversion of phenylalanine to tyrosine by microorganisms. Canadian Journal of Microbiology 14, 573-578.

CraWford, R. L. \& FrICK, T. D. (1977). Rapid spectrophotometric differentiation between glutathione-dependent and glutathione-independent gentisate and homogentisate pathways. Applied and Environmental Microbiology 34, 170-174.

Crawford, R. L., Hutton, S. W. \& Chapman, P. J. (1975). Purification and properties of gentisate 1,2dioxygenase from Moraxella osloensis. Journal of Bacteriology 121, 794-799.

DuINE, J. A. \& Frank, J. (1981). Methanol dehydrogenase: a quinoprotein. In Proceedings of the Third International Symposium on Microbial Growth on $C_{1}$ compounds, pp. 31-41. Edited by H. Dalton. London: Heyden.

Freese, E., Sheu, C. W. \& Galliers, E. (1973). Function of lipophilic acids as antimicrobial food additives. Nature, London 241, 321-325.

FrIEDRICH, B. \& Schlegel, H. G. (1972). Die Hydroxylierung von Phenylalanin durch Hydrogenomonas eutropha $\mathrm{H16}$. Archives of Microbiology 83, 1731.
Guroff, G. \& Ito, T. (1964). Phenylalanine hydroxylation by Pseudomonas species (ATCC 11299a). Journal of Biological Chemistry 240, 1175-1184.

Hagedorn, S. R. \& Chapman, P. J. (1985). Glutathione-independent maleylacetoacetate isomerase in Gram-positive bacteria. Journal of Bacteriology 163, 803-805.

Hagedorn, S. R., Bradley, G. \& Chapman, P. J. (1985). Glutathione-independent isomerization of maleylpyruvate by Bacillus megaterium and other Gram-positive bacteria. Journal of Bacteriology 163 , 640-647.

HotTA, S. S. (1968). Oxidative metabolism of isolated brain mitochondria: changes caused by aminooxyacetate. Archives of Biochemistry and Biophysics 127, 132-139.

Hummel, W., Weiss, N. \& KulA, M.-R. (1984). Isolation and characterization of a bacterium possessing L-phenylalanine dehydrogenase activity. $\mathrm{Ar}$ chives of Microbiology 137, 47-52.

LACK, L. (1959). The enzymic oxidation of gentisic acid. Biochimica et biophysica acta 34, 117-123.

Marshall, V. P. \& SoKaTCH, J. R. (1968). Oxidation of D-amino acids by a particulate enzyme from Pseudomonas aeruginosa. Journal of Bacteriology 95, 1419-1424.

Nakamori, S., Yokozeki, K., Mitsugi, K., Eguchi, E. \& IwAGami, H. (1980). Method for producing D- $\alpha$-amino acid. United States Patent no. 4211840.

Nakata, H., Yamauchi, T. \& Fugisawa, H. (1979). Phenylalanine hydroxylase from Chromobacterium violaceum. Purification and characterization. Journal of Biological Chemistry 254, 1829-1833.

Olivieri, R., FAscetti, E., ANGelini, L. \& Degen, L. (1979). Enzymatic conversion of $N$-carbamoyl-Damino acids to D-amino acids. Enzyme and Microbial Technology 1, 201-204.

Olivieri, R., Fascetti, E., Angelini, L. \& Degen, L. (1981). Microbial transformation of racemic hydantoins to D-amino acids. Biotechnology and Bioengineering 23, 2173-2183. 
Pioli, D., Venables, W. A. \& Franklin, F. C. H. (1976). D-Alanine dehydrogenase. Archives of Microbiology 110, 287-293.

SCHUTT, H. (1981). Stereoselective resolution of phenylglycine derivatives and 4-hydroxyphenylglycine derivatives with enzyme resins. United States Patent no. 4260684

Schutt, H., Schmidt-Kastner, G., ARens, A. \& Preiss, M. (1985). Preparation of optically active Darylglycines for use as side chains for semisynthetic penicillins and cephalosporins using immobilized subtilisins in two-phase systems. Biotechnology and Bioengineering 27, 420-433.

Stirling, D. I. \& Dalton, H. (1978). Purification and properties of an NAD(P)+-linked formaldehyde dehydrogenase from Methylococcus capsulatus (Bath). Journal of General Microbiology 107, 1929.

Takahashi, S., Ohashi, T., Kil, Y., Kumagai, H. \& YAMADA, H. (1979). Microbial transformations of hydantoins to $N$-carbamyl-D-amino acids. Journal of Fermentation Technology 57, 328-332.
TsuKaDA, K. (1966). D-Amino acid dehydrogenase of Pseudomonas fluorescens. Journal of Biological Chemistry 241, 4522-4528.

VAN DEN TWeel, W. J. J., SMits, J. P. \& DE Bont, J. A. M. (1986a). Microbial metabolism of D- and L-phenylglycine by Pseudomonas putida LW-4. Archives of Microbiology 144, 169-174.

VAN DEN TWEEL, W. J. J., JANSSENS, R. J. J. \& DE BONT, J. A. M. (1986b). Degradation of 4-hydroxyphenylacetate by Xanthobacter $124 \mathrm{X}$; physiological resemblance with other Gram-negative bacteria. Antonie van Leeuwenhoek 52, 309-318.

Yamada, S., Hongo, C., Yoshioka, R. \& Chibata, I. (1979). Preparation of D-p-hydroxyphenylglycine. Optical resolution of DL-p-hydroxyphenylglycine with $d$-3-bromocamphor-8-sulfonic acid. Agricultural and Biological Chemistry 43, 395-396.

YAMANAKA, K. (1981). Comparative aspects of methanol dehydrogenases. In Proceedings of the Third International Symposium on Microbial Growth on $C_{1}$ compounds, pp. 21-30. Edited by H. Dalton. London: Heyden. 